\title{
INTERVENSI GURU TERHADAP EKSPRESI TUTUR SISWA TUNARUNGU
}

\author{
Suko Winarsih \\ FKIP Universitas Kanjuruhan Malang \\ e-mail: farida.umi34@yahoo.com
}

\begin{abstract}
Abstrak
Penelitian ini bertujuan mendeskpripsikan intervensi guru terhadap tuturan siswa tunarungu, mencakup intervensi terhadap tindak tutur, fungsi tutur, dan strategi bertutur. Penelitian ini menggunakan rancangan deskriptif kualitatif. Data penelitian ini berupa data deskriptif dan data reflektif. Data dianalisis berdasarkan teori pragmatik, khususnya pragmatik klinis (clinical pragmatics). Hasil penelitian sebagai berikut. Pertama, intervensi terhadap tindak tutur meliputi tindak tutur ilokusi, kemampuan percakapan, pemahaman, dan narasi. Kedua, intervensi terhadap fungsi tutur meliputi intervensi direktif dan intervensi fasilitatif. Ketiga, intervensi guru terhadap strategi bertutur meliputi manipulasi konteks dan intervensi presimbolik dan simbolik minimal.
\end{abstract}

Kata kunci: intervensi guru, tindak tutur, ekspresi tutur, siswa tunarungu

\section{TEACHERINTERVENTIONS IN DEAF STUDENTS' ORAL EXPRESSIONS}

\begin{abstract}
This study aims to describe teacher interventions in deaf students' oral expressions, comprising those in speech acts, speech functions, and speech strategies. It employed the qualitative descriptive approach. The data comprised descriptive and reflective data. They were analyzed by means of pragmatics theory, especially clinical pragmatics. The findings are as follows. First, interventions in speech acts include illocutionary acts, conversation capabilities, understanding, and narration. Second, interventions in speech functions include directive and facilitative interventions. Third, interventions in speech strategies include context manipulation and pre-symbolic and minimum symbolic interventions.
\end{abstract}

Keywords: teacher interventions, speech acts, oral expressions, deaf students

\section{PENDAHULUAN}

Pragmatik klinis merujuk pada deskripsi dan klasifikasi kerusakan kompetensi pragmatik dan memberikan penjelasan teoretis mengenai variasi pragmatik, linguistik, kognitif, dan neurologi, serta cara melakukan asesmen dan treatmen terhadap mereka. Kemampuan dan ketidakmampuan pragmatik merupakan dampak dari interaksi yang kompleks antara semiotik, kognitif, dan sistem sensorimotor. Munculnya pragmatik klinis sebagai sebuah studi tersendiri disebabkan oleh adanya perkembangan di bidang psikologi, neurologi, dan pragmatik. Salah satu permasalahan yang dikaji di dalam pragmatik klinis adalah ketunarunguan.

Penyebab ketunarunguan sebagian besar adalah faktor bawaan. Ketunarunguan bawaan terjadi karena keturunan atau sebagai akibat adanya toksin sejak masa prakelahiran ataupun sebab-sebab lain. Ketunarunguan yang terjadi karena sesuatu hal disebabkan oleh berbagai macam toksin atau infeksi telinga spesifik, misalnya, media otitis (Carrow-Woolfolk dan Lynch, 1982:371). 
Penyebab ketunarunguan bawaan tertinggi adalah faktor keturunan (Konigsmark, 1972; dan Northern dan Downs, 1978:378; dalam Carrow-Woolfolk dan Lynch, 1982:371). Studi mereka menyimpulkan bahwa hampir 50\% ketunarunguan bawaan adalah faktor keturunan. Akan tetapi, 40\% dari kasus keturunan tersebut adalah akibat warisan kromosom yang terpendam, yang berarti bahwa kedua orang tua adalah pembawa gejala yang sama. Sebagian besar orang tua dari anak-anak tunarungu tidak mempunyai riwayat ketunarunguan dan bahkan pendengarannya normal. Hal ini, tentu saja, memperumit masalah ketunarunguan secara keturunan. Konigsmark (1972:89-99) mengidentifikasi lebih dari 60 jenis ketunarunguan karena faktor keturunan dan memberikan kriteria untuk membedakannya. Dari hasil observasinya diketahui bahwa dari keenampuluh jenis ketunarunguan tersebut tidak satupun yang berhubungan dengan keanehan fisik. Akan tetapi, terdapat sejumlah kecacatan kelahiran yang jelas yang berhubungan dengan ketunarunguan.

Penyebab utama ketunarunguan bawaan yang tidak berasal dari keturunan adalah toksin yang menyerang ibu saat bulan-bulan awal kehamilan. Toksin yang umum menyerang adalah rubella dan cytomegalovirus (Northern dan Downs, 1978: 386), dan penyebab lain, seperti syphilis, toxemia dan diabetes. Evaluasi klinis pendengaran seharusnya dilakukan sedini mungkin sejak awal kelahiran anak untuk mengantisipasi resikotinggiterhadapgangguan pendengaran. Faktor-faktor resiko tinggi tersebut adalah: (1) riwayat keturunan ketunarunguan di dalam keluarga,

(2) virus rubella yang menyerang ibu hamil, (3) infeksi yang fatal, (4) kerusakan atau kecacatan telinga, hidung dan tenggorokan, (5) kelahiran bayi dengan berat badan kurang dari 1500 gram, (6) serum bilirubin lebih dari 20 miligram per 100 milimeter, dan (7) potensi cytomegalovirus bawaan (Lloyd dan Dahle, 1976:12-22).
Anak yang lahir dengan pendengaran normal mungkin kehilangan pendengarannya selama masa kanak-kanak karena berbagai penyakit, seperti: campak atau cacar air, penyakit gondong, meningitis (radang selaput otak atau tulang belakang), enchepalitis (radang otak) dan infeksi lain akibat penggunaan obat-obat ototoksik yang mengakibatkan kehilangan pendengaran secara serius. Selain itu, ketunarunguan juga disebabkan oleh infeksi telinga (akut, kronis atau media otitis serius). Batasan ketunarunguan tidak terbatas pada kehilangan pendengaran yang sangat berat, melainkan juga mencakup seluruh tingkat kehilangan pendengaran dari tingkat ringan, sedang, berat sampai sangat berat.

Menurut Moores (1978:173-194) definisi ketunarunguan ada dua kelompok. Pertama, seseorang dikatakan tuli apabila kehilangan kemampuan mendengar pada tingkat $70 \mathrm{~dB}$ Iso atau lebih. Ia tidak dapat mengerti pembicaraan orang lain melalui pendengarannya baik dengan ataupun tanpa alat bantu mendengar. Kedua, seseorang dikatakan kurang dengar bila kehilangan pendengaran pada $35 \mathrm{~dB}$ Iso. Ia mengalami kesulitan memahami pembicaraan orang lain melalui pendengarannya baik tanpa maupun dengan alat bantu mendengar.

Tuli merupakan kerusakan organ dalam telinga, termasuk syaraf-syaraf yang menghubungkannya ke otak dalam menerima rangsangan semua jenis bunyi. Orang tuli tidak dapat menggunakan pendengarannya untuk dapat mengartikan pembicaraan, walaupun sebagian pembicaraan dapat diterima, baik tanpa maupun dengan alat bantu dengar. Sementara kurang dengar adalah kondisi seseorang yang kehilangan pendengarannya secara nyata yang memerlukan penyesuaian khusus. Tuli maupun kurang mendengar dikatakan sebagai ganggunan pendengaran (hearing impaired) (Carrow-Woolfolk dan Lynch, 1982:376). 
Perkembangan bahasa pada anak tunarungu digolongkan atas: (1) pralingual, awal usia 3 tahun dan sebelum akuisisi kode bahasa, dan (2) pravokasional, mulai usia 18 tahun (Nortthern dan Downs, 1978:372). Pada anak tunarungu pralingual, tujuan utama pelatihan adalah menentukan bahasa. Remediasi utama pada tunarungu pravokasional adalah mempertahankan kemampuan berbahasanya dan melanjutkan perkembangannya.

Berikut ini adalah model interaksi dan percakapan antara seorang guru, Ibu Rini dan Niken, siswa kelas XI tunarungu. Konteksnya, pada saat itu hari Jumat, waktunya pelajaran keterampilan dan kesenian. Hari sebelumnya, Kamis juga pelajaran keterampilan. Siswa-siswa mempelajari cara membuat hantaran, yaitu teknik mengemas oleh-oleh yang berupa busana untuk calon pengantin perempuan dengan berbagai pola kemasan yang sangat indah dan menarik, misalnya berupa bangun binatang, unggas, kucing, dan lain-lain. Siswa-siswa pada hari Kamis itu langsung pulang karena jam sekolah berakhir. Mereka lupa tidak membereskan sampah kertas koran yang berserakan. Hari Jumat, Ibu Rini melihat meja keterampilan yang penuh dengan sampah koran. Karena yang berada di dekatnya adalah Niken, maka $\mathrm{Bu}$ guru Rini berbicara dengan Niken. Berikut ini dialognya.

Bu Rini: “Niken, coba ke sini!” (menepuk bahu Niken)

Niken menoleh kepada Bu Rini. Dia membaca gerak bibir bu Rini.

Niken : "Ya Bu! Ada apa?" (dengan artikulasi yang terbatas)

Bu Rini: "Kemarin, setelah selesai pelajaran keterampilan membuat hantaran kok korannya tidak dibersihkan!" (gerak bibir dalam mengucapkan kalimat tersebut agak lambat dan dibantu oleh gerak tangan untuk memperjelas maksud)

Niken belum mengerti perkataan bu Rini. Niken : "Apa?"
Bu Rini: "Kemarin... membuat hantaran... koran berserakan."

(Bu Rini mengulanginya dengan kalimat yang lebih sederhana dan gerak tangan yang lebih mudah dipahami oleh Niken).

Bu Rini: "Membuat hantaran... koran berserakan." (mengulangi dengan bahasa yang lebih sederhana dan dibantu dengan gestur tertentu)

Niken membaca gerak bibir dan gerak tangan bu Rini.

Niken : "Anak-anak pulang." (Maksudnya: $Y a \mathrm{Bu}$, kemarin teman-teman terburuburu pulang sehingga tidak sempat membereskan korannya

Niken secepatnya membersihkan koran-koran bekas yang berserakan di meja dan di lantai.

Pada contoh dialog tersebut, hal yang menarik diinvestigasi adalah bagaimana siswatunarungu mengekspresikan tuturan dan bagaimana seorang guru melakukan intervensi terhadap ekspresi tutur siswa tersebut. Sebagai siswa tunarungu, Niken berusaha memperhatikan ujaran gurunya. Niken berinisiasi dalam interaksi tersebut dengan cara menatap mata guru yang mengajaknya berbicara dan mendekat kepada guru yang menepuk bahunya.

Dalam hal komunikasi yang lain, ketika Niken memberitahukan kepada Bu Rini bahwa kemarin teman-temannya terburu-buru pulang sehingga tidak sempat membereskan kertas koran yang berserakan di meja. Ini merupakan ekspresi tindak ilokusi asertif. Pada ilokusi ini si penutur terikat oleh kebenaran proposisi yang diungkapkan (Leech, 1986:164). Selanjutnya, intervensi yang dilakukan oleh guru adalah mengulang kalimat (repeating). Selain itu, Bu Rini berusaha menyampaikan ujarannya secara lebih sederhana dan lebih pendek. Dalam hal ini, guru mengoptimalkan sistem komunikasi dengan cara menyederhanakan ujaran dengan mengemukakan kata kunci, berbicara dengan lambat dan gerak bibir yang sangat jelas supaya siswa dapat 
mengerti melalui lips reading. Berdasarkan hal-hal yang telah diuraikan, pengkajian pragmatik klinis dalam penelitian ini difokuskan pada intervensi guru terhadap ekspresi tutur siswa tunarungu.

\section{METODE}

Penelitian ini menggunakan rancangan deskriptif kualitatif, dengan tujuan mendeskripsikan data penelitian secara faktual dan alamiah. Penelitian dilakukan di SMALB-B YPTB (Yayasan Pendidikan Tunas Bangsa) yang berlokasi di Jalan Brigjend Slamet Riadi 126 Kecamatan Klojen Kota Malang Jawa Timur 65112. Subjek penelitian adalah (1) para guru, berjumlah 5 orang dan (2) siswa kelas XII (enam orang), kelas XI (tiga orang), dan kelas X (tujuh orang) SMALB-B YPTB (Yayasan Pendidikan Tunas Bangsa).

Data penelitian berupa: (1) data deskriptif dan (2) data reflektif. Pertama, data deskriptif ditampilkan dalam bentuk: (a) transkripsi tuturan yang diproduksi oleh siswa tuna rungu dan guru dalam proses interaksi pembelajaran di kelas, yang ditransfer berdasarkan rekaman wacana utuh dari video recorder, dan (b) penggalan tuturan, yang terdiri atas dua macam: (i) penggalan tuturan yang diujarkan oleh siswa tuna rungu, dan (ii) penggalan tuturan yang diujarkan oleh para guru. Data itu merupakan data utama untuk menganalisis dan menjawab rumusan masalah mengenai intervensi guru terhadap ekspresi tutur siswa tuna rungu dalam interaksi pembelajaran di kelas. Kedua, data reflektif berupa catatan lapangan berdasarkan observasi langsung untuk menggambarkan konteks yang melatarbelakangi hadirnya tuturan. Dalam penelitian ini, peneliti merupakan instrumen kunci yang bertugas mengumpulkan data, memvalidasikan data, menganalisis data, dan menyimpulkan hasil penelitian. Instrumen pendukung yang digunakan dalam proses pengumpulan data berupa video recorder.
Teknik pengumpulan data yang dilakukan meliputi: (1) teknik penjaringan data dan (2) prosedur pengumpulan data. Teknik penjaringan data yang digunakan adalah: (1) teknik perekaman, (2) teknik observasi, dan (3) teknik dokumentasi. Prosedur pengumpulan data yang dilakukan: (1) persiapan pengumpulan data, (2) perekaman, (3) observasi, dan (4) wawancara.

Setelah perekaman data dilakukan, selanjutnya data ditranskripsikan. Kegiatan transkripsi ini dilakukan melalui dua cara. Pertama, data rekaman ditranskripsi menggunakan tulisan tangan. Setelah itu dilakukan pengecekan terhadap transkripsi tulisan tangan tadi. Kedua, hasil transkripsi tulisan tangan yang sudah benar diketik dengan menggunakan komputer. Hal ini dimaksudkan agar data transkripsi dapat diakses dengan mudah berdasarkan tujuan penelitian.

Data yang telah ditranskrispsikan diolah menggunakan prosedur pengolahan data kualitatif, yaitu: (1) reduksi data, (2) kodifikasi data, (3) display data, (4) analisis data, (5) intrerpretasi data, dan (6) penyimpulan dan verifikasi. Data yang telah ditranskripsikan direduksi (disortir, dipilih dan dipilah) dengan cara membaca kembali secara cermat. Reduksi data dilakukan pada saat pemberian kode atau proses kodifikasi data pada penggalan-penggalan tuturan yang diproduksi, baik oleh siswa tuna rungu maupun para guru.

Data yang telah diolah, selanjutnya dianalisis, dengan menggunakan prosedur: (1) intrerpretasi data, dan (2) penyimpulan dan verifikasi. Kegiatan interpretasi data dilakukan dalam proses analisis data dengan menggunakan tabel atau carta data terpiih yang telah dibuat. Interpretasi data dikategorikan berdasarkan fokus penelitian: (1) wujud tutur, (2) kendala tutur, dan (3) intervensi guru terhadap ekspresi tutur anak tuna rungu dalam interaksi pembelajaran di kelas. Data yang 
berupa penggalan-penggalan tuturan yang telah dikodifikasikan dianalisis dengan cara memasukkannya ke dalam slot-slot atau kolom-kolom berdasarkan indikator-indikator yang telah diidentifikasi. Penyimpulan dan verifikasi merupakan proses akhir pada penelitian ini. Dalam proses penyimpulan dan verifikasi ini, peneliti melakukan konsultasi secara berkesinambungan dan intensif dengan para dosen pembimbing dan berdiskusi dengan teman-teman sejawat yang memiliki kompetensi dalam bidang ini sebagai triangulasi. Apabila penarikan kesimpulan benar-benar diyakini dan telah melalui proses yang benar dengan didukung oleh data-data yang valid, dibuatlah kesimpulan akhir penelitian.

Pengecekan data dan hasil temuan penelitian disesuaikan dengan rancangan penelitian kualitatif untuk memperoleh validasi dan kesimpulan yang meyakinkan. Pengecekan data dan hasil temuan dilakukan melalui tiga cara. Pertama, validasi kecukupan data diperlukan untuk analisis data, keintensifan dan kesinambungan dalam pengambilan data untuk memperoleh derajat keterpercayaan data yang terjaring. Kedua, sistematisasi data berupa korpus data. Korpus data tersebut dicek kecukupan, kelengkapan, dan keakuratannya. Pengecekan data dilakukan dengan: (1) membaca data secara cermat dan berulang-ulang, (2) melakukan pengamatan dan penelusuran data secara cermat berdasarkan rumusan masalah penelitian, dan (3) melakukan penelusuran terhadap penelitian lain yang relevan. Ketiga, pengecekan data hasil analisis dilakukan dengan para dosen pembim-bing dan teman-teman sejawat dalam bentuk kegiatan seminar hasil penelitian. Hal itu dilakukan agar dapat dihasilkan suatu temuan atau hasil penelitian yang menyeluruh atau komprehensif dan dapat dipertanggungjawabkan secara akademis.

\section{HASIL PENELITIAN DAN PEMBA- HASAN}

Intervensi guru terhadap ekspresi tutur siswa tunarungu di dalam interaksi pembelajaran di kelas meliputi tiga hal, yaitu (1) intervensi terhadap tindak tutur, (2) intervensi terhadap fungsi tutur, dan (3) intervensi terhadap strategi bertutur. Deskripsi intervensi tersebut diuraikan pada subbagian berikut.

\section{Intervensi terhadap Tindak Tutur}

Hasil analisis data menunjukkan bahwa intervensi terhadap tindak tutur yang dilakukan oleh guru meliputi empat aspek, yaitu (1) intervensi tindak tutur ilokusi, (2) intervensi kemampuan percakapan, (3) intervensi pemahaman, dan (4) intervensi narasi. Deskripsi intervensi guru terhadap tindak tutur diuraikan berikut ini.

Pertama, intervensi tindak tutur ilokusi yang dilakukan oleh guru terhadap ekspresi tutur siswa tunarungu tercermin dalam lima indikator. Kelima indikator tersebut adalah (1) meminta perhatian, (2) meminta tindakan, (3) meminta klarifikasi, (4) meminta informasi, dan (5) meminta objek

Intervensi guru dengan cara meminta perhatian siswa merupakan suatu tindakan untuk memancing perhatian siswa terutama dalam kegiatan memulai pelajaran. Pada contoh carta data terpilih, hal yang dilakukan oleh guru untuk meminta perhatian siswa adalah menyapa (greeting). Contohnya adalah ujaran Bu Ludvi sambil ia menulis materi di papan tulis untuk memusatkan perhatian siswa."Sekarang, kita akan belajar tentang pencemaran sumber daya alam."(LV22).

Intervensi guru dengan meminta tindakan siswa bertujuan mendapatkan respon yang berupa tindakan (action) pada siswa. Untuk tujuan tersebut, guru memberikan ujaran berupa kalimat imperatif. Contohnya:ujaran Bu Asih pada pelajaran Penjaskes dengan topik pembahasan 
dampak negatif narkoba, "Sekarang Sholeh cerita!" (AS40). Melalui tuturan itu, Bu Asih menugasi seorang siswa kelas XI yang bernama Sholeh menceritakan pengalamannya di depan kelas sehubungan dengan topik yang dibahas pada pelajaran Penjaskes pagi itu, yaitu narkoba.

Intervensi guru dapat juga dilakukan dengan cara meminta klarifikasi kepada siswa, dengan harapan siswa merespon dengan tindak tutur tertentu. Bu Ludvi meminta klarifikasi kepada siswa pada saat menerangkan topik perawatan jenazah. Berikut ini tuturan Bu Ludvi, "Mengunjungi orang sakit, kalau laki-laki bajunya dibuka, memakai kaca mata hitam, boleh?" (LV105). Menanggapi pertanyaan Bu Ludvi tersebut, secara spontan Sholeh dan Niken menjawab, "Tidak boleh."

Guru seringkali meminta informasi kepada siswa sebagai stimulus agar siswa bersedia berbicara. Contoh pada cara data terpilih menunjukkan bahwa guru bertanya kepada siswa untuk meminta informasi, khususnya hal-hal yang berkaitan dengan materi atau topik pembelajaran pada waktu itu. Contohnya ketika Bu Ludvi bertanya kepada Reni, "Reni di rumah ada pohon apa?" (LV39b). Atas pertanyaan Bu Ludvi itu, dengan artikulasi yang cukup jelas Reni menjawab "Kelapa, rambutan, papaya." Ibu Ludvi berhasil melakukan intervensi terhadap tindak tutur dengan cara memita informasi kepada Reni, sebagai siswa baru kelas X SMALB-BYPTB Malang. Reni dapat menjawab dengan jelas karena ia masih mempunyai kemampuan mendengar yang lumayan baik.

Selain meminta informasi guru juga melakukan intervensi dari segi tindak tutur ilokusi dengan cara meminta objek kepada siswa. Tujuannya adalah siswa merespon permintaan tersebut dengan memberikan objek yang dikehendaki oleh guru. Dengan demikian, harapan guru adalah tuturannya mempunyai daya perlokusi yang efektif. Contohnya ujaran
Bu Ludvi pada saat menerangkan dan memeragakan contoh perbuatan tercela pada pelajaran Agama Islam di kelas XII, "Pinjam!" Ya contoh." (LV261). Bu Ludvi meminjam HP Lina sebagai contoh untuk memeragakan hal yang diterangkannya. Tetapi karena Lina lama menanggapi atau merespon ujaran Bu Ludvi, Niken memberikan HP-nya kepada Bu Ludvi.

Kedua, hasil analisis data pada cara data terpilih menunjukkan bahwa intervensi kemampuan percakapan tercermin dalam lima indikator: (1) presuposisi, (2) menyarankan berdiskusi, (3) meminta penjelasan detail, (4) meminta pendapat, dan (5) pemerbaikan percakapan.

Presuposisi adalah praanggapan atau asumsi latar belakang hadirnya suatu ujaran yang konteksnya telah diketahui bersama, baik oleh penutur maupun oleh mitra tutur. Dalam istilah sederhana, presuposisi adalah anggapan yang melatarbelakangi hadirnya tuturan. Contoh datanya adalah ujaran Bu Ludvi berikut ini, "Bu Ludvi berangkat dari rumah jam 06.00 sampai di sekolah jam 6.30 (isyarat). Jadi waktu perjalanan 30 menit (menulis di papan). Sita, masuk jam 6 lebih 5 menit (menulis di papan). Bu Ludvi naik sepeda motor waktunya 30 menit, Sita naik mikrolet (isyarat) 5 menit?" (LV36). Bu Ludvi mempertanyakan kelogisan pernyataan Sita. Artinya, Bu Ludvi ingin menunjukkan kepada siswa bahwa pernyataan Sita tidak masuk akal dengan presuposisi tertentu. Presuposisinya adalah (1) letak rumah Bu Ludvi lebih dekat ke sekolah daripada letak rumah Sita, (2) Bu Ludvi berangkat ke sekolah tiap pagi mengendarai sepeda motor, sedangkan Sita naik mikrolet, dan (3) perjalanan yang ditempuh Bu Ludvi selama 30 menit, sedangkan Sita hanya 5 menit. Jadi, suatu hal yang wajar apabila Bu Ludvi mempertanyakan pernyataan Sita yang tidak logis.

Contoh intervensi guru menyarankan siswa berdiskusi adalah ujaran Bu Rini pada pelajaran bahasa Indonesia berikut 
ini. "Sekarang bentuk kelompok! Coba cari satu masalah! Tadi sudah tahu toh masalah... bukan masalah? Coba cari satu masalah! Coba cari satu masalah, tentukan sendiri! Pecahkan... diskusi... bercakap-cakap... omongomong!" (RN488).

Dengan ujaran tersebut, Bu Rini bermaksud menyarankan siswa untuk berdiskusi memecahkan suatu masalah yang topiknya dipilih sendiri oleh siswa.

Guru meminta penjelasan secara detail kepada siswa sebagai cara intervensi kemampuan percakapan. Dengan cara ini guru berharap siswa tunarungu dapat melakukan komunikasi verbal. Contohnya adalah ujaran Bu Ludvi berikut ini, "Coba jawab jujur! Kenapa tidur jam dua belas?" (LV237). Bu Ludvi meminta penjelasan kepada Sholeh dengan meminta alasan kenapa Sholeh tadi malam tidur pukul dua belas.

Intervensilain yang dilakukanolehguru adalah guru meminta pendapat siswa. Contohnya adalah ujaran Bu Rini berikut ini, "Mengapa bukan masalah?" (RN437). Pada saat itu pelajaran Bahasa Indonesia dengan topik memecahkan masalah. Bu Rini memancing siswa dengan sebuah kasus, yaitu kegiatan upacara pada setiap hari Senin. Bu Rini meminta pendapat Lina mengapa kegiatan latihan upacara untuk hari Senin baginya bukan merupakan masalah.

Intervensi guru melakukan pemerbaikan percakapan terhadap ujaran siswa tampak pada contoh ujaran Bu Asih, "Tidur gak bisa, jadi melek. Tidur ndak bisa apa ndak bisa bangun?" (AS54). Bu Asih berusaha memperbaiki ujaran Sholeh yang tidak tepat. Seharusnya Sholeh mengatakan bahwa Yusuf tidak bisa bangun, bukan Yusuf tidur tidak bisa.

Ketiga, temuan penelitian menunjukkan bahwa intervensi pemahaman dilakukan oleh guru dengan lima cara, yaitu (1) memberikan pemahaman referensial, (2) memanipulasi isi semantik, (3) performansi topik, (4) pemeliharaan topik, dan (5) mengulang.
Guru memberikan pemahaman referensial terhadap objek tingkah laku akademis, sikap akademis atau referensi linguistik. Contohnya adalah ujaran $\mathrm{Bu}$ Rini, "Para hadirin sekalian... tidak boleh! Hadirin itu tamu... sudah banyak, orangorang banyak... itu hadirin." (RN34). Bu Rini memberikan pemahaman referensi linguistik bahwa kata "hadirin" sudah menunjukkan jamak sehingga tidak perlu diberi artikel "para" dan "sekalian".

Dalam intervensinya, guru dapat juga melakukan manipulasi semantik. Artinya, untuk membantu pemahaman siswa terhadap suatu objek atau kata leksikal guru menjelaskannya dengan berbagai cara, misalnya dengan memberikan definisi, sinonim, antonim, ilustrasi atau contohcontoh penggunaan kata tersebut dalam konstruksi kalimat. Contoh kongkretnya adalah ujaran Bu Ludvi, "Apa arti kumuh? Rumah (dibantu dengan isyarat jari tangan) kalau di pinggir sungai, sering kita lihat di Jakarta. Rumah di pinggir sungai kan jelek-jelek, gampang roboh, tidak ada genting, tetapi dari bambu. Jika ada angin besar (isyarat) rumah bergerak-gerak. Mencuci, mandi, air jadi satu, tidak ada air bersih. Kalau di Malang di mana? Jalan Brantas dekat Senaputra, jalannya sempit, rumah tidak ada jendela, jendela hanya satu, tidur satu tempat tidur untuk lima orang. Kamar mandi samasama (isyarat), tidak sendiri-sendiri (isyarat). Satu rumah tidak mempunyai satu kamar tidur, kamar mandi antri panjang (isyarat), rumah banyak, kecil-kecil, tetapi kamar mandinya hanya satu. (Dilanjutkan materi) Berkurangnya lahan untuk hewan. Hewan dipelihara di kebun binatang." (LV48b).

Dengan performansi topik guru berharap siswa-siswa benar-benar memahami topik yang sedang dibahas. Performansi topik biasanya berupa penjelasan panjang lebar dari guru tentang materi atau topik tertentu, lengkap dengan pengertian istilah dan ilustrasinya. Contohnya adalah ujaran Bu Ludvi yang menerangkan topik pencemaran. "Sekarang terjadinya 
pencemaran suara (kebisingan). Kalian tidak bisa mendengar, tetapi bisa merasakan atau mencium dari baunya (menunjuk hidung sebagai isyarat 'bisa mencium'). Kalau sepeda motor digas (isyarat) dengan keras, maka knalpot (Bu Ludvi menuliskan kata 'knalpot' di papan tulis) akan mengeluarkan asap. Itu namanya pen-ce-ma-ran (menunjuk kata 'pencemaran' yang tertulis di papan tulis). Kecuali kalau di lapangan, ada lapangan balapan, ada balapan mobil, ada balapan sepeda motor, jadi ndak apa-apa. Sepeda motor dan mobil boleh menggunakan suara yang keras dan kecepatan tinggi untuk balapan (isyarat). Tetapi, kalo di jalan raya? Mengganggu?" (LV25).

Setelah menampilkan topik guru melakukan pemeliharaan terhadap topik tersebut dalam rangka melakukan intervensi pemahaman terhadap siswa-siswa tunarungu. Pemeliharaan topik dilakukan oleh guru dengan cara memberikan tugas kepada siswa-siswa berdasarkan topik, misalnya siswa tunarungu diberi tugas membaca biodata, membaca puisi, berpidato, bercerita, menjadi MC dan lain-lain. Cara lain adalah guru memberikan ilustrasi berupa kasus rekayasa yang melibatkan nama-nama siswa untuk menimbulkan kesan seolah-olah siswa terlibat di dalamnya. Seperti contoh ujaran Bu Ludvi: "Kalau bohong berarti kita tidak mendapatkan apa-apa. Contoh, Niken tadi bohong... Niken tidak mendapatkan apaapa. Tapi kalau menipu... Bu Ludvi tadi kan mendapatkan keuntungan uang... berarti itu menipu." (LV270). Pada ujaran itu, Bu Ludvi memberikan ilustrasi seolah-olah Niken melakukan salah satu perbuatan tercela, yaitu berbohong.

Intervensi pemahaman dilakukan dengan cara mengulang (repeating) kata-kata kunci agar siswa tunarungu benar-benar paham terhadap materi yang sedang didiskusikan. Berdasarkan pengamatan di lapangan, tindakan ini sering dilakukan oleh guru dalam menanamkan pengertian dan pemahaman materi kepada siswasiswa. Contohnya, ujaran Bu Rini, "Fakta... yang betul terjadi, yang sedang terjadi... yang terjadi... yang betul... yang sedang terjadi." (RN198).

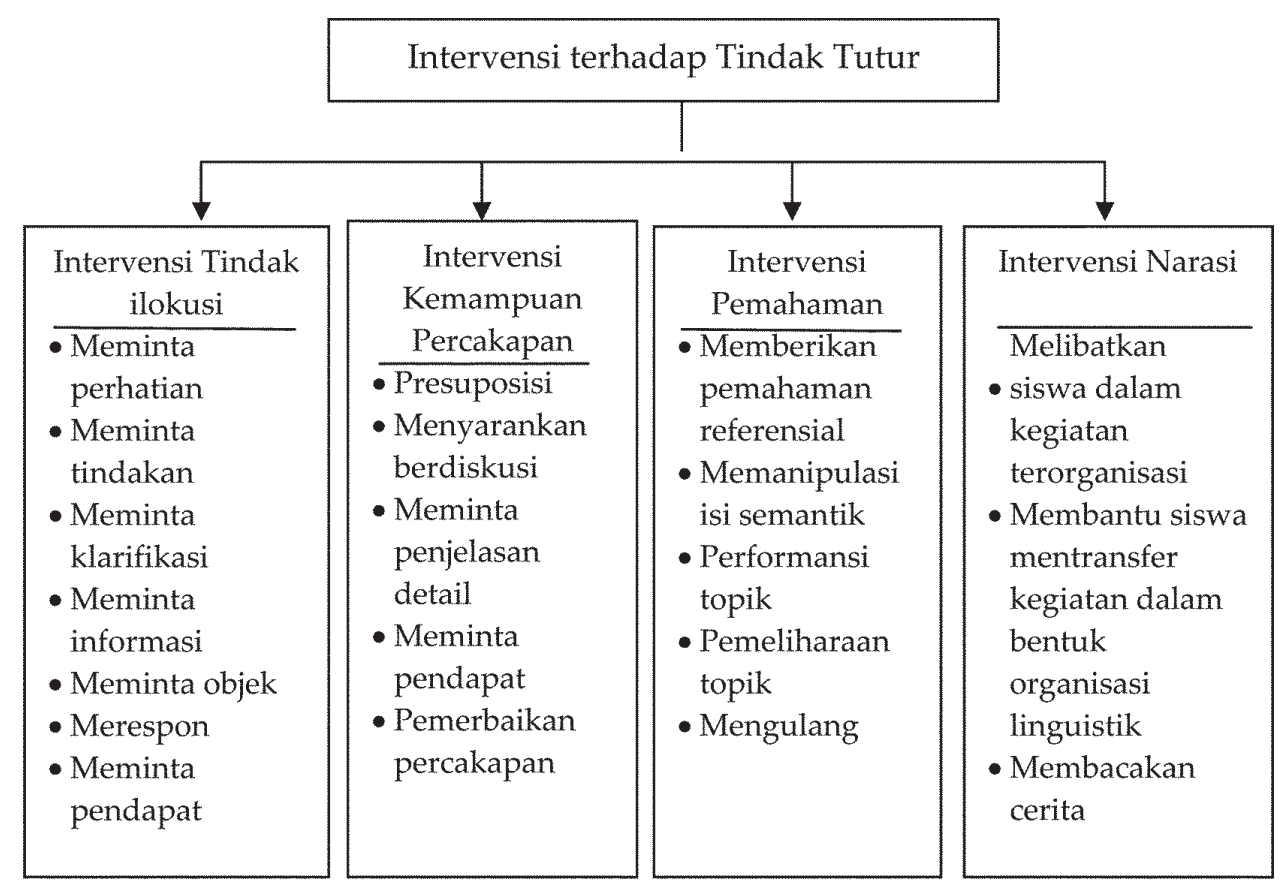

Bagan 1. Pola Intervensi Guru terhadapTindak Tutur 
Kelima, hasil analisis data menunjukkan bahwa intervensi narasi oleh guru dilakukan melalui tiga cara, (1) melibatkan siswa dalam kegiatan terorganisasi, (2) membantu siswa mentransfer kegiatan dalam bentuk organisasi linguistik, dan (3) membacakan cerita.

Guru melibatkan siswa dalam kegiatan terorganisasi. Contohnya adalah ujaran Bu Rini, yang menugasi siswa mencari bacaan di koran dan menganalisis kata ulang yang terdapat di dalam bacaan tersebut. "Coba dicari! Di dalam cerita pasti ada kata ulang. Nanti di rumah membawa sendiri, membawa bacaan yang di dalamnya ada kata ulang. Coba dicari! Di dalam cerita... dicari kata ulang! Digarisbawahi yang ada kata ulang, digarisbawahi, ya? Ya, besok dibawa bacaannya!"(RN143).

Guru membantu siswa mentransfer kegiatan dalam bentuk organisasi linguistik. Contohnya, "Kamu cerita pengalamanmu!" (AS77). Bu Asih menugasi Sholeh menceritakan pengalamannya ketika Luqman bercerita kepadanya mengenai Yusuf yang mencuri HP.

Bentuk intervensi lainnya, guru membacakan cerita. Berikut ini adalah ujaran Bu Rini pada pelajaran seni dan budaya. Bu Rini melatih siswa memerankan salah satu adegan dalam naskah drama Tangkuban Perahu, "Aduh, benangku jatuh. Bagaimana ini? Dayang Sumbi mengambilnya, manja, manja." (RN83). Bu Rini membaca penggalan naskah drama Tangkuban Perahu dan memberikan contoh ekspresi mimik dan pantomimik kepada Lina yang berperan sebagai Dayang Sumbi. Pola intervensi guru terhadap tindak tutur disajikan pada Bagan 1.

\section{Intervensi Guru terhadap Fungsi Tutur}

Hasil analisis data menunjukkan bahwa intervensi guru terhadap fungsi tutur mempunyai dua cara, yaitu (1) intervensi secara direktif dan (2) intervensi secara fasilitatif. Pertama, guru melakukan intervensi secara direktif melalui empat cara, yaitu (1) berinisiasi separuh dari percakapan, (2) menggunakan pertanyaan langsung, (3) menggunakan imitasi atau ekspansi untuk mengatur topik, dan (4) menggunakan kalimat imperatif. Kedua, intervensi guru secara fasilitatif meliputi: (1) berinisiasi kurang dari separuh percakapan, (2) menggunakan pertanyaan tidak langsung, (3) menggunakan pernyataan untuk mengatur topik, dan (4) memberikan pemindahgiliran.

Dalam intervensinya secara direktif salah satu cara yang dilakukan oleh guru adalah berinisiasi separuh dari percakapan. Guru menjelaskan topik yang dibahas. Contohnya, ujaran Bu Rini pada mata pelajaran Bahasa Indonesia, "Ide pokoknya ini. (Bu Rini menggarisbawahi bagian ide pokok bencana yang dijadikan sarana untuk memungut uang dari masyarakat). Jadi, ide pokoknya ini, mau ngomong ... berita... mau omong... mau bicara bahwa bencana tsunami, gempa bumi dijadikan sarana untuk memungut uang dari masyarakat, bagaimana? Banyak organisasi, kelompok orang meminta sumbangan untuk membantu bencana. Mereka mengatasnamakan dari departemen sosial. Ini bercerita ... mau omong ... mau menceritakan...mau bicara bahwa bencana itu dijadikan sarana tempat untuk memungut (menggunakan isyarat jari tangan), meminta uang dari masyarakat." (RN510).

Guru menggunakan pertanyaan langsung kepada siswa sebagai cara lain dalam melakukan intervensi dari segi fungsi tutur secara direktif. Contohnya adalah adalah ujaran Bu Rini, "Iya... nama siapa? Yang menjadi tokoh siapa? Itu kan yang menjadi tokoh...tokoh siapa nama?" (RN126). Pada tuturan tersebut Bu Rini bertanya kepada siswa mengenai nama-nama tokoh di dalam sinetron Cinta Fitri yang dicontohkan oleh siswa.

Dalam intervensinya secara direktif guru membuat imitasi (tiruan, model, contoh, analogi) dan ekspansi atau perluasan terhadap topik yang sedang dibahas. Misalnya, ujaran Bu Ludvi pada pelajaran 


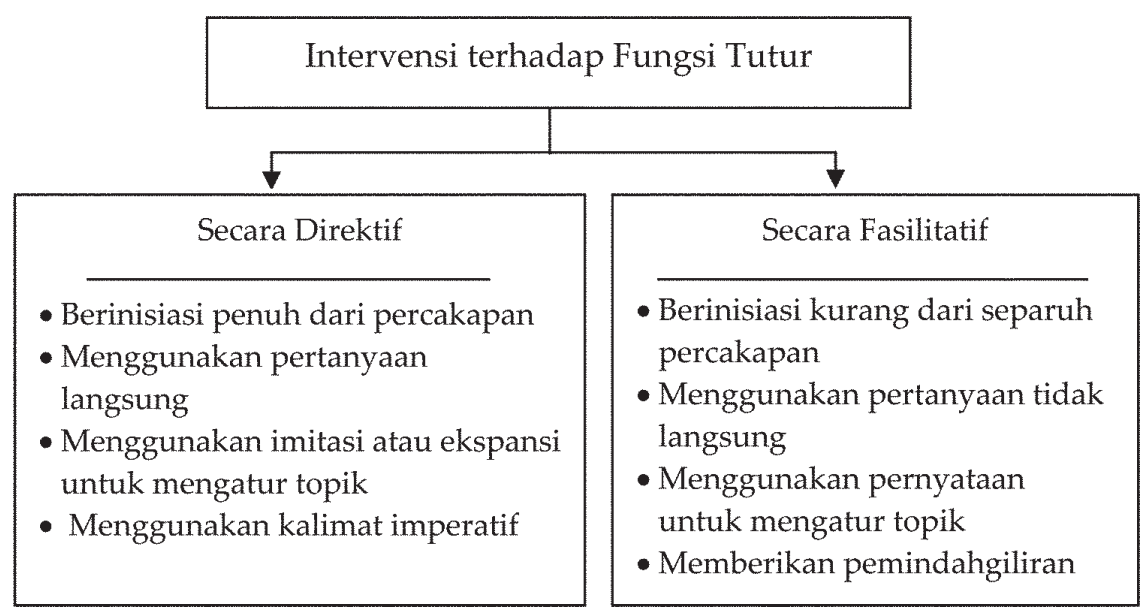

Bagan 2. Pola Intervensi Guru terhadap Fungsi Tutur

Intervensi terhadap Strategi Bertutur

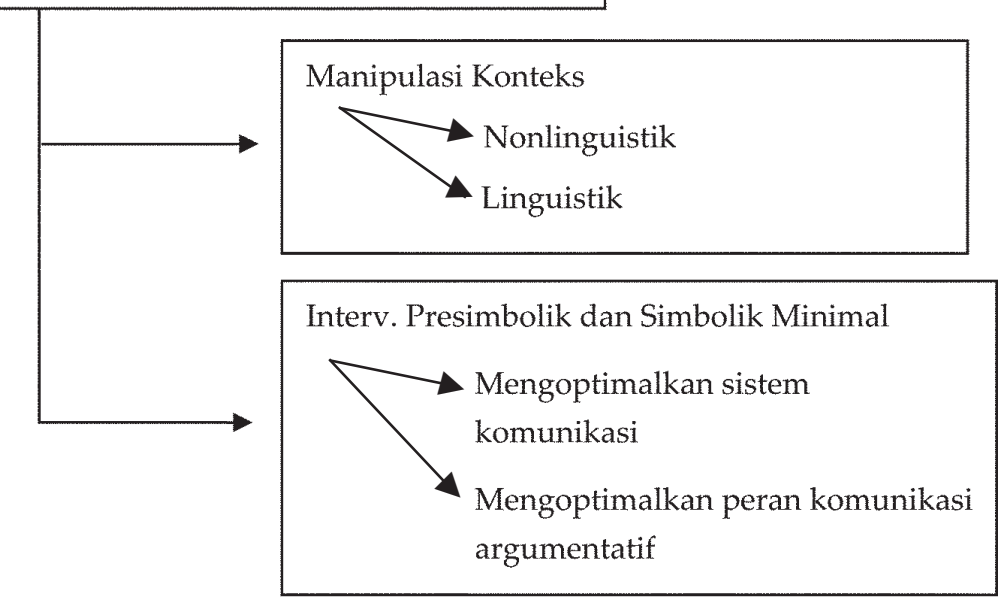

Bagan 3. Pola Intervensi Guru terhadap Strategi Bertutur

agama Islam dengan topik zakat, "Jadi, kalau menimbang beras harus dilihat betul atau kurang (dibantu dengan menggunakan isyarat jari tangan). Dua koma lima itu ditimbang... dilihat. Dua koma lima itu satu orang. Kalau harga beras, misalnya, Bu Ludvi mempunyai uang sepuluh ribu, Bu Ludvi bisa membeli beras berapa?" (LV154). Bu Ludvi melakukan ekspansi dengan contoh soal agar siswa memberikan jawabannya dengan tepat.

Dengan menggunakan kalimat imperatif guru berharap siswa dapat mengomunkasikan gagasannya secara ver- bal. Contohnya adalah ujaran $\mathrm{Bu}$ Asih, "Kamu cerita pengalamanmu!" (AS77). Bu Asih meminta Alfandi menceritakan pengalamannya sehubungan dengan topik narkoba pada pelajaran penjaskes.

Berkebalikan dengan intervensi secara direktif, pada intervensi fasilitatif guru berinisiasi kurang dari separuh percakapan. Artinya, guru hanya sedikit memberikan penjelasan mengenai topik yang dibahas.Contohnya adalah ujaran Bu Asih, "Sekarang Sholeh cerita!" (AS40). Bu Asih meminta Sholeh bercerita pengalamannya sehubungan dengan topik 
dampak negatif narkoba pada pelajaran penjaskes. Ujaran Bu Asih tersebut merupakan bentuk intervensi dari segi fungsi tutur secara fasilitatif dengan cara berinisiasi separuh dari percakapan. Bu Asih memilih cara menugasi Sholeh bercerita pengalamannya sehubungan dengan topik yang sedang dibahas pada saat itu, yaitu narkoba dan dampak negatifnya.

Intervensi guru secara fasilitatif dapat pula dilakukan dengan menggunakan pertanyaan tidak langsung, seperti contohya ujaran Bu Rini "Antagonis... tokoh yang..." (RN133). Bu Rini bertanya kepada siswa pengertian tokoh antagonis dengan menggunakan pernyataan. Bu Rini berharap siswa melanjutkan pernyataannya itu.

Guru menggunakan pernyataan untuk mengatur topik. Contohnya ujaran Bu Ludvi, "Ya, kemarin pergi tidak pamit." (LV230). Bu Ludvi mengatakan bahwa Niken, Dinia, dan Susi pada hari Sabtu Idul Qurban pergi ke MTD (Malang Tempo Doeloe) tanpa pamit kepada bapak/ibu guru. Pernyataan ini dikemukakan dalam rangka mengatur topik yang sedang dibahas, yaitu perbuatan tercela (berbohong). Bu Ludvi berharap Niken memberikan komentarnya. Niken membantah tuduhan itu. Ia mengatakan bahwa ia dan temantemannya sudah berpamitan kepada Pak Yayak. Dari percakapan itu akhirnya terjadi perdebatan antara Niken dan $\mathrm{Bu}$ Ludvi.

Intervensi secara fasilitatif dilakukan oleh guru dengan memberikan pemindahgiliran kepada siswa. Contohnya adalah ujaran Bu Rini, "Ya, Riska!” (RN54b). Pada waktu itu pelajaran Bahasa Indonesia dengan topik membaca biodata. Beberapa siswa kelas $X$ sudah maju membacakan biodata. Kemudian Bu Rini memindahgilirkan tugas dari siswa lain kepada Riska untuk maju memperkenalkan diri. Intervensi guru terhadap fungsi tutur dapat dipolakan seperti Bagan 2.

\section{Intervensi Guru terhadap Strategi Ber- tutur}

Hasil analisis data pada instrumen atau carta data terpilih mencerminkan bahwa intervensi guru terhadap strategi bertutur mempunyai dua cara, yaitu (1) manipulasi konteks dan (2) intervensi presimbolik dan simbolik minimal.

Pertama, manipulasi konteks yang dilakukan oleh guru adalah (1) manipulasi konteks nonlinguistik dan (2) manipulasi konteks linguistik. Satu-satunya data yang ditemukan dari hasil analisis mengenai manipulasi konteks nonlinguistik adalah ujaran Bu Ludvi, "Bu Ludvi tidak ada." (LV57). Setelah mengutarakan ujaran itu Bu Ludvi keluar ruang kelas dengan harapan Dinia mau bercerita tentang topik pencemaran lingkungan kepada teman-temannya di depan kelas. Bu Ludvi merasa bahwa Dinia malu-malu untuk bercerita, sehingga Bu Ludvi punya inisiatif keluar ruang kelas agar Dinia tidak malu bercerita kepada teman-temannya.Contoh manipulasi konteks linguistik adalah ujaran Bu Rini, "Coba lagi ya! Masalah atau Bukan. Di ruang internet... halaman depan selalu kotor sehingga siswa-siswa SMALB tidak dapat belajar dengan baik. Masalah atau bukan?"(RN347).

Kedua, hasil penelitian menunjukkan bahwa terhadap strategi bertutur siswa, guru melakukan intervensi presimbolik dan simbolik minimal. Intervensi presimbolik adalah campur tangan guru dalam mengembangkan keterampilan tertentu. Selanjutnya, intervensi simbolik minimal adalah campur tangan guru dalam mengembangkan keterampilan sehubungan dengan fungsi ilokusi. Indikator-indikatornya (1) mengoptimalkan sistem komunikasi dan (2) mengoptimalkan peran komunikasi argumentatif.

Ujaran Bu Rini berikut ini adalah cara mengoptimalkan sistem komunikasi, "Ade... vokal sudah bagus. Orang sudah tahu. Kita harus banyak belajar. Lihat cermin! $a, i, u$, e, o...jelas? Terus...terus... setiap pagi... sholat 
sudah... olah raga... senam mulut." (RN52a). $\mathrm{Bu}$ Rini memberikan pendapat tentang pengucapan atau artikulasi Ade dan juga memberikan nasihat kepada Ade untuk terus melatih pengucapan artikulatorisnya agar lebih bagus.

Ujaran Bu Ludvi, “Kenapa?" (LV65) merupakan cara Bu Ludvi untuk mengoptimalkan peran komunikasi argumentatif. Bu Ludvi ingin tahu alasan Reni mengatakan bahwa lahan yang dulu dingin sekarang menjadi panas. Bu Ludvi berharap Reni memberikan argumentasi secara lisan. Pola intervensi guru pada strategi bertutur disajikan pada Bagan 3.

\section{SIMPULAN}

Guru melakukan berbagai intervensi terhadap tindak tutur, fungsi tutur, dan strategi bertutur siswa tunarungu. Dengan melakukan intervensi, para guru di SLB (Sekolah Luar Biasa) Tunarungu sekaligus bertindak sebagai terapis. Guru berusaha memotivasi siswa untuk dapat berbicara seoptimal mungkin melalui berbagai cara yang termaktub ke dalam ketiga jenis intervensi tersebut. Guru berkomitmen tinggi untuk mempersiapkan siswa didik tunarungu agar dapat berkomunikasi di lingkungan masyarakat tanpa bergantung kepada isyarat-isyarat tubuh (body language), sehingga diharapkan mereka dapat bersosialisasi. Hasil penelitian menunjukkan bahwa intervensi yang dilakukan oleh guru merupakan stimulus bagi siswa tunarungu untuk berbicara secara optimal. Proposisi ilmiah yang dapat dirumuskan adalah intensitas intervensi guru terhadap ekspresi tutur siswa tunarungu berdampak positif dan efektif dalam memotivasi mereka untuk berbicara.

Berdasarkan hasil penelitian dikemukakan saran-saran berikut ini. Para dosen atau tenaga pengajar pada program studi Bahasa dan Sastra Indonesia (Fakultas Sastra) dan program studi Pendidikan Bahasa dan Sastra Indonesia (FKIP) disarankan untuk mengembangkan silabus dan materi perkuliahan semantik, pragmatik, dan psikolinguistik dengan mengembangkannya pada disorder bahasa siswatunarungu.

Para guru SLB tunarungu disarankan dapat menangani siswa dalam hal kemampuan berbicara, menyimak pembicaraan, ekspresi menulis, memahami bacaan, kelancaran membaca, berhitung, dan berpikir matematis (memecahkan masalah). Selain itu, para guru tersebut disarankan dapat memberikan treatmen dan terapi terhadap masalah kesalahan ejaan, kesalahan membedakan hal yang didengar, kesulitan mengenal huruf, kesulitan menangkap dan mengucapkan bunyi-bunyi bahasa tertentu, kesalahan membilang dan mengenal kembali angka, kesulitan mengingat, dan kesalahan ucapan unsur kata.

Para pengembang kurikulum untuksekolah berkebutuhan khusus atau berkesulitan belajar, terutama SLB-B (tunarungu) disarankan dapat mengembangkan kurikulum dan silabus yang mempunyai karakter khusus ketunarunguan. Kepada para peneliti lanjut diharapkan melakukan penelitian-penelitian lain yang sejenis, yaitu penelitian yang berhubungan dengan kompetensi pragmatik siswa dengan disorder bahasa (language disorder), misalnya siswa autisme, keterbelakangan mental (mental retardation), Down's Syndrome, William's Syndrome, Asperger's Syndrome, dan lain-lain.

\section{UCAPAN TERIMA KASIH}

Terima kasih diucapkan kepada Promotor, yaitu Bapak Prof. Dr. H. Abdul Syukur Ibrahim, dan kedua Ko-promotor, yaitu Bapak Prof. Dr. H. Suparno dan Bapak Dr. H. Nurhadi, M.Pd yang telah memberikan kritik, masukan, arahan, dan saran kepada peneliti mengenai isi dan teknik penulisan penelitian ini. Selain itu, juga diucapkan terima kasih kepada warga SMALB-B YPTB (Yayasan Pen- 
didikan Tunas Bangsa) Malang. Mereka adalah para guru, yaitu Bapak Minatsir, Ibu Ash Suprapti, Ibu Ludfia, Ibu Rini, dan Bapak Yahya, dan siswa kelas X, XI, XII yang telah memberikan kesempatan untuk menjaring data penelitian.

\section{DAFTAR PUSTAKA}

Carrow-Woolfolk, E. \& Lynch, JI. 1982. Integrative Approach to Language in Child-ren. New York: Grune \& Stratton, In

Konigsmark, B. 1972. Genetic HearingLoss with NoAssociated Abnormality:A Review. Journal Speech Hearing Disorder 37
Leech, Geoffrey. 1986. Principles of Pragmatics. Longman: Longman Group UK Limited

Lloyd, L., \& Dahle, A. 1976. “Detection and Diagnosis of a Hearing Impairment in the Child". Volta Review 78

Moores, DF. 1978. Current Research and Theory with the Deaf: Educational Implications. Dalam Liben, LS (Ed). Deaf Children: Developmental Perspectives. New York: Academic Press

Northern, JL., \& Downs, MP. 1978. Hearing in Children (ed 2). Baltimore: Wiliams $\&$ Wilkins 